\title{
KETAATAN HUKUM PEDAGANG DALAM MEMBAYAR RETRIBUSI PASAR DI PT. SABHO KARYA ALAM KECAMATAN PASARWAJO KABUPATEN BUTON
}

\author{
La Juju, Sulfa, Wa Ode Reni \\ Jurusan Pendidikan Pancasila dan Kewarganegaraan \\ Fakultas Keguruan dan Ilmu Pendidikan \\ Universitas Halu Oleo
}

Email:lajuju2267@gmail.com, sulfasaulaubo@gmail.com,waodereni06@gmail.com

Abstrak: Tujuan yang hendak dicapai dalam penelitiian ini adalah: 1.Untuk mengetahui ketaatan hukum terhadap pedagang dalam membayar Retribusi pasar di pasar Sabho Kecamatan Pasarwajo Kabupaten Buton. 2. Untuk mengetahui upaya yang dilakukan dalam meningkatkan ketaatan hukum terhadap Pedagang dalam membayar retribusi pasar di pasar Sabho Kecamatan Pasarwajo Kabupaten Buton.

Pendekatan yang digunakan dalam penelitian ini adalah pendekatan mixmethode (Campuran) atau kualitatif/kuantitatif.Responden dalam penelitian ini berjumlah 45 orang dari unsur Pedagang. Informan penelitian berjumlah 4 orang. Terdiri dari Manajer pasar sabho, petugas akuntansi, 2 orang petugas penagih retribusi berjumlah. Teknik pengumpulan data yaitu: observasi, wawancara, kuesioner dan dokumentasi. Tehnik analisis data sebagaimana yang dikemukakan oleh miles Huberman terdiri pengumpulan data, reduksi data, verifikasi data dan penarikan kesimpulan.

Hasil penelitian ini menunjukkan bahwa, ketaatan hukum pedagang dalam membayar retribusi pasar sudah cukup baik, hal ini dipengaruhi oleh tiga ketaatan hukum yaitu: (1) ketaatan yang bersifat Compliance artinya pedagang taat dalam membayar retribusi disebabkan karena takut diberikan sanksi oleh petugas pengelola pasar. (2) ketaatan yang bersifat Indentification yaitu taat karena adanya penghargaan yang diberikan oleh pengelola pasar dan takut hubungan dengan pihak pengelola pasar menjadi rusak. (3) ketaatan yang bersifat Internalizationyaitu pedagang taat dalam membayar retribusi pasar karena adanya kesadaran dalam diri sendiri.

Upaya yang selalu diterapkan di pasar Sabho untuk meningkatkan ketaatan hukum pedagang dalam membayar retribusi pasar diantaranya yaitu: (a) Pengelolaan Manajemen yaitu dilakukanoleh seorang manager pasaryang tugasnya memimpin, mengarahkan,dan menetapkan jadwal pembayaran retribusi pasar, baik itu pembayaran yang ditetapkan perhari maupun perbulan, agar pedagang membayar retribusi pasar sesuai dengan waktu yang ditentukan. (b) Pengawasan, yaitu para petugas penagih melakukan pengawasan,dan penagihan untuk meningkatkan pembayaran rteribusi pasar.

Kesimpulan penelitian ini yaitu pedagang taat dalam membayar retribusi pasar, karena takut diberikan sanksi oleh petugas pengelola pasar.Upaya yang dilakukan petugas pengelola pasar yaitu melakukan Pengelolaan Manajemen dan pengawasan agar semua pedagang taat membayar retribusi pasar.

Kata Kunci: Retribusi Pasar; Ketaatan Hukum Pedagang. 


\title{
TRADERS' LAW COMPLIANCE IN PAYING OF MARKET RETRIBUTION IN PT. SABHO KARYA ALAM, PASARWAJO DISTRICT, BUTON REGENCY
}

\author{
La Juju, Sulfa, Wa Ode Reni \\ Civic Education Department \\ Faculty of Teacher and Training Education \\ Halu Oleo University
}

Email: 1ajuju2267@gmail.com, sulfasaulaubo@gmail.com, waodereni06@gmail.com

\begin{abstract}
The objectives of this study are: 1. to determine the legal compliance toward market retribution traders in the Sabho market, Pasarwajo District, Buton Regency. 2. To measure the efforts made in increasing legal compliance with traders in paying market fees in the Sabho market, Pasarwajo District, Buton Regency.

The approach used in this study was a mixed-method or qualitative/quantitative approach. The informants were 4 people, including the Sabho market manager, accounting officer, 2 retribution collection officers. Data collection techniques were observation, interviews, questionnaires, and documentation. The data analysis technique proposed by Miles Huberman consisted of data, data reduction, data levers, and data retrieval.

The results of this study indicated that the legal compliance of traders in paying market retribution was good enough. It was obtained by three law compliance, namely: (1) compliance which means that traders are obedient in paying retribution because they are given responsibility by market management officers, (2) identification compliance, namely compliance because of the award given by the market manager and afraid of the damaged relationship with the market manager, (3) internalization compliance, that is, traders obey in paying market fees because of their awareness. Efforts that were always applied in the Sabho market to increase merchant legal compliance in paying market retribution, namely: (a) management is carried out by a manager whose job is to lead, direct, manage the schedule market retribution payments whether the payments are set daily or monthly so that traders pay market retributionbased on the specified time. (b) oversight is the collection officers supervise and collect to increase payments for market distribution.

The conclusion is that traders are compliant in paying market fees because they are willing to impose sanctions by market management officers. The effort made by the management officer is to carry out management and supervision so that all traders obey the pay market levies.
\end{abstract}

Keywords: Market Retribution; Traders' Law Compliance

\section{PENDAHULUAN}

Pasar dalah tempat bertemunya pembeli dan penjual, tempat tersebut merupakan sarana bagi pembelidan penjual melakukan transaksi-transaksi perdagangan guna memenuhi segala kebutuhan-kebutuhannya. Transaksi dalam pasar dilakukan melalui tukar menukar barang atau barter. Namun seiring dengan perkembangan zaman, manusia tidak lagi melakukan tukar menukar barang atau barter, tetapidengan menggunakan uang sebagai alat pembayarannya. Fungsi pasar sendiri merupakan salah satu sarana pokok untuk menggerakkan dan meningkatkan perekonomian masyarakat disuatu daerah. Pemerintah daerah selaku pihak yang berkuasa dan berwenang harus mengambil peranan dalam penertiban dan penataan pasar supaya berjalan baik dan lancar. Dalam upaya meningkatkan kemandirian daerah perlu dilakukan optimalisasi penerimaan sumber-sumber 
PAD, salah satunya dengan meningkatkan penerimaan retribusi daerah khususnya retribusi pasar. Retribusi pasar adalah sejumlah pungutan yang dibebankan oleh setiap pedagang yang berjualan di suatu pasar. Retribusi pasar biasanya terdiri dari retribusi kebersihan, retribusi parkir khusus, retribusi MCK, ataupun retribusiretribusi yang lain. Retribusi Pelayanan Pasar menurut Peraturan Daerah Kota Pasarwajo Kabupaten ButonNo 4 Tahun 2013 tentang retribusi pelayanan pasar bahwa berdasarkan pasal 110 ayat (1) huruf (F) Undang-undang Nomor 28 Tahun 2009 tentang pajak daerah dan retribusi daerah, retribusi pelayanan pasar merupakan salah satu jenis retribusi jasa umum yang dapat dipungut oleh pemerintah daerah. Jasa retribusi pelayanan pasar didasarkan atas luas, jenis tempat dan kelas pasar yang digunakan. Berdasarkan peraturan daerah Kabupaten Buton No.4 tahun 2013 Bab V bahwa besarnya tarif retribusi sebagaimana yang dimaksud pasal 7 ayat 1 prinsip dan sasaran dalam penetapan tarif retribusi ditetapkan dengan memperhatikan biaya penyediaan fasilitas pasar, kemampuan masyarakat, aspek keadilan, dan efektivitas pengendalian atas pelayanan tersebut. Rincian retribusi di Kabupaten Buton pada tanggal 20 Februari 2018 untuk reteribusi pelayanan pasar website resmi Kabupaten Buton pendapatan perjenis retribusi pada APBD 2017 Per 20 Februari 2018.

Namun pencapaian pembayaran retribusi pasar masih terbilang belum maksimal pedagang membayar retribusi pertahun hal ini, dikarenakan pihak yang berwajib masih kurang teliti dalam menangani masalah retribusi dan kurangnya pengawasan dari pihak yang berwajib serta kurangnya sanksi yang tegas kepada pihak yang enggan membayar retribusi. Berdasarkan observasi awal di pasar Sabho Kabupaten Buton para pedagang pasar dalam membayar retribusi pasar masih ada rasa mengeluh sebagian pedagang dalam membayar retribusi pasar dan sebagian belum sesuai dengan biaya yang ditentukan dan tepat pada waktu yang ditentukan, untuk itu penulis tertarik mengangkat sebuah penelitian yang berjudul Ketaatan hukum Pedagang Dalam Membayar Retribusi Pasar di Pasar Sabho karya alam Kecamatan Pasarwajo Kabupaten Buton.

\section{Konsep Kesadaran}

Kesadaran secara harfiah, kesadaran sama artinya dengan mawas diri (awareness) kesadaran juga bisa diartikan kondisi dimana seseorang individu memiliki kendali penuh terhadap stimulus internal maupun stimulus eksternal namun kesadaran juga menyangkut dalam persepsi dan pemikiran yang secara samar-samar disadari oleh individu sehingga akhirnya perhatiannya terpusat.

Atosokni (2002:7) mendefinisikan kesadaran diri sebagai pemahaman terhadap kekhasan fisik, kepribadian, watak, dan temperamennya mengenal bakatbakat alamiah yang dimilikinya dan punya gambaran atau konsep yang jelas tentang diri sendiri dengan segala kekuatan dan kelemahannya.

\section{Kesadaran Hukum Dan Ketaatan Hukum}

Kesadaran hukum menurut kamus besarbahasa indonesia adalah kesadaran seseorang akan pengetahuan bahwa suatu perilaku tertentu diatur oleh hukum. (Anna: 2005). Sementara menurut Affandi (1998:38) menyebutkan bahwa kesadaran hukum merupakan kesadaran atau nilai-nilai yang terdapat didalam diri manusia tentang hukum yang ada atau tentang hukum yang diharapkan ada, sebenarnya yang ditetapkan adalah nilai-nilai tentang fungsi hukum dan bukan suatu penilaian hukum terhadap kejadian yang konkrit didalam masyarakat yang bersangkutan. 


\section{Ketaatan Hukum}

Ketaatan hukum tidak lepas dari kesadaran hukum, dan kesadaran hukum yang baik adalah ketaatan hukum, dan ketidaksadaran hukum yang baik adalah ketidaktaatan. Pernyataan ketaatan hukum. Ketaatan sendiri dapat dibedakan dalam tiga jenis, menurut H.C Kelman (Kamaruddin, 2016: 150)

1. Ketaatan yang bersifat compliance, yaitu jika seseorang menaati suatu aturan, hanya karena takut terkena sanksi. Kelemahan ketaatan jenis ini, Karena membutuhkan pengawasan yang terus-menerus.

2. Ketaatan yang bersifat indentification, yaitu jika seseorang menaati satu aturan, hanya karena takut hubungan baiknya dengan pihak lain menjadi rusak.

3. Ketaatan yang bersifat internalization, yaitu jika seseorang menaati suatu aturan, benar-benar karena merasa ba bahwa aturan itu sesuai dengan nila-nilai intristik yang dianutnya.

\section{Konsep Retribusi Daerah}

Retribusi daerah sebagaimana halnya pajak daerah merupakan salah satu pendapatan asli daerah yang diharapkan menjadi salah satu sumber pembiayaan penyelenggaraan pemerintahan dan pembangunan daerah, untuk meningkatkan dan meratakan kesejahteraan masyarakat. Mardiasmo (2009:100)

\section{Konsep Retribusi Pasar}

Retribusi pelayanan pasar yang selanjutnya disebut retribusi adalah pungutan daerah sebagai pembayaran atas pemanfaatan dan/ atau penggunaan fasilitas pasar tradisional /sederhana, berupa pelataran, los, kios yang dikelola pemerintah daerah.(Peraturan Daerah Kabupaten Buton Nomor 4 Tahun 2013 Bab 1 tentang retrbusi pelayanan pasar).

\section{Upaya-upaya Pemerintah Untuk Meningkatkan Ketaatan Hukum Pedagang Dalam Membayar Retribusi Pasar}

\section{Sumber Daya Manusia}

Menurut Werher dalam Sutrisno (2009:4) bahwa sumberdaya manusia (SDM) adalah" pegawai yang siap,mampu,dan siaga dalam mencapai tujuantujuan organisasi',. Sedangkan menurut Payaman (1998:1) SDM atau human resources mengandung dua pengertian. Pertama SDM mengandung pengertian usaha kerja atau jasa yang dapat diberikan dalam proses produksi. Pengertian kedua dari SDM menyangkut manusia yang mampu bekerja untuk memberikan jasa atau usaha kerja tersebut mampu bekerja, berarti mampu melakukan kegiatan yang mempunyai nilai ekonomis,yaitu bahwa kegiatan tersebut menghasilkan barang atau jasa untuk memenuhi kebutuhan masyarakat.

\section{Pengelolaan manajemen}

Manajemen (pengelolaan) menurut Setyawan (2004:10) adalah suatu kegiatan organisasi,sebagai suatu usaha dari sekelompok orang yang bekerja sama dalam rangka mencapai suatu tujuan tertentu yang mereka nanti sedemikian rupa sehingga diharapkan hasil yang akan dicapai sempurna yaitu efektif dan efisien. Menurut Terry dalam Andi (2010:18) definisi manajemen sebagai berikut:'suatu proses yang membeda-bedakan atau perencanaan, pengorganisasian, pelaksanaan, dan pengawasan dengan memanfaatkan baik 
ilmu maupun seni, agar dapat mencapai suatu tujuan yang telah ditetapkan sebelumnya.' Maka dapat disimpulkan bahwa pengertian pengelolaan adalah suatu proses kegiatan yang meliputi perencanaan, pengorganisasian, pelaksanaan dan pengawasan yang bertujuan menggali dan memanfaatkan sumberdaya alam yang dimiliki secara efektif untuk mencapai tujuan organisasi yang telah ditentukan.

\section{Pengawasan}

Menurut Revrisond (1999:118) yang dimaksud dengan pengawasan adalah suatu kegiatan untuk memperoleh kepastian apakah pelaksanaan pekerjaan atau kegiatan itu dilakukan sesuai dengan rencana, aturan-aturan sesuai dan tujuan yang telah ditetapkan.

\section{Regulasi}

Menurut Hartono (2002:69).Regulasi berasal dari bahasa inggris, yakni regulation atau peraturan. Dalam kamus bahasa Indonesia kata "peraturan mengandung arti kaidah yang dibuat untuk mengatur, petunjuk yang dipakai untuk menata sesuatu sesuai dengan aturan, dan ketentuan yang harus dijalankan dan dipatuhi dalam proses pengelolaan organisasi publik, baik pada organisasi pusat, pemerintah daerah, partai politik, yayasan, LSM, organisasi keagamaan/tempat peribadatan, maupun organisasi sosial masyarakat sosial lainnya.

\section{Konsep pedagang}

Menurut Sudirmansyah,(2011) pedagang adalah orang yang mencari nafkah dengan berdagang. Pedagang adalah orang yang menjalankan usaha berjualan, usaha kerajinan, atau usaha pertukangan kecil. Pedagang dapat dikategorikan menjadi:

a) Pedagang Grosir, beroperasi dalam rantai distribusi antara produsen dan pedagang eceran.

b) Pedagang Eceran, disebut juga pengecer menjual produk komoditas langsung kepada konsumen.

Menurut Hentiani (2011) dalam pasar tradisional pedagang dibedakan menjadi dua, yaitu pedagang kios dan pedagang non kios.

a) Pedagang Kios adalah pedagang yang menempati bangunan kios di pasar.

b) Pedagang Non Kios adalah pedagang yang menempati tempat selain kios, yaitu dalam los, luarlos, dasaran dan palyon.

\section{METODE PENELITIAN}

\section{Lokasi dan Waktu Penelitian}

Lokasi penelitian ini dilaksanakan di Pasar Sabho Kecamatan Pasar Wajo Kabupaten Buton. Alasan peneliti memilih Pasar Sabho sebagai lokasi penelitian yaitu peneliti melihat bahwa dalam proses pembayaran retribusi pasar, ketaatan hukum pedagang dalam membayar retribusi masih rendah. Penelitian ini telah dilaksanakan pada bulan Agustus 2019.

\section{Pendekatan Penelitian}

Pendekatan yang digunakan dalam penelitian ini adalah pendekatan mixmethode atau kualitatif kuantitatif yang bersifat deskritif yaitu peneliti memberikan gambaran atau penjelasan dengan menggunakan fakta-fakta, data, dan informasi secara detail mengenai kesadaran masyarakat dalam membayar retribusi pasar. 


\section{Subyek Penelitian}

Subjek penelitian ini terdiri atas responden yang berjumlah 45 orang pedagang di Pasar Sabho, dan informan penelitian berjumlah 4 orang terdiri dari 1 manajer, 1 bidang akutansi, dan 2 petugas penagih retribusi pasar Shabo Kecamatan Pasarwajo Kabupaten Buton

\section{Teknik Pengumpulan Data}

Adapun teknik pengumpulan data yang akan digunakan dalam penelitian ini yaitu teknik observasi, wawancara,kuesioner,dan dokumentasi.

1. Observasi, dilaksanakan untuk keperluan pengumpulan data dengan cara mengamati, memotret dan mencatat secara sistematis mengenai aktivitas pedagang di Pasar Sabho.

2. Wawancara mendalam, yaitu peneliti mengajukan pertanyaan langsung kepada subjek penelitian untuk memperoleh informasi seacara rinci dan mendalam sesuai dengan permasalahan yang diteliti.

3. Dokumentasi, yaitu pengumpulan data yang sudah ada, data yang dimaksud berupa gambaran data hasil penerimaan retribusi.

4. Kuesioner/angket, adalah suatau alat pengumpulan data yang berupa serangkaian pertanyaan tertulis yang dapat diajukan kepada subyek untuk mendapatkan jawaban secara tertulis.

\section{Teknik Analisis Data}

Teknik analisis data dalam penelitian ini adalah analisis deskriptif kualitatif. Menurut Miles dan Huberman (Hamid, 2014: 7-8) analisis data yang dilakukanmelalui empat tahap yaitu pengumpulan data, reduksi data, penyajian data / data display dan penarikan kesimpulan.

1. Pengumpulan data yaitu dilakukan pengumpulan data hasil observasi, hasil wawancara dan hasil dokumentasi berdasarkan kategorisasi yang sesuai dengan masalah penelitian.

2. Reduksi data yaitu, merangkum, memilih hal yang pokok, memfokuskan pada hal yang penting, dicari pola dan temanya.

3. Penyajian data, yaitu penyajian data dalam bentuk uraian singkat, bagan dan hubungan antar kategori.

4. Penarikan kesimpulan, yaitu peneliti menyusun kesimpulan yang masih sementara dan dilakukan verifikasi secara berkesinambungan, sehingga pada akhirnya disusun kesimpulan akhir yang ditujukan untuk menjawab semua masalah yang menjadi fokus penelitian.

\section{HASIL DAN PEMBAHASAN \\ Hasil Penelitian}

Kegiatan dan pendahuluan

Pada tanggal 25 Agustus 2019 diadakan proses wawancara dan pembagian angket yang berlangsung selama 90 menit proses wawancara dan pembagian angket ini bertujuan untuk mengetahui jumlah pedagang yang taat dalam membayar retribusi pasar. Pada pengambilan angket ini diperoleh jumlah pedagang yang taat pada ketaatan hukum yang bersifat complianceberjumlah $55,55 \%$ pedagang yang taat dalam membayar retribusi pasar, selanjutnya pedagang yang taat dalam membayar retribusi pasar pada ketaatan hukum yang bersifat indentification berjumlah $31,11 \%$ dan pedagang yang membayar retribusi pasar karena adanya penghargaan kepada pengelola pasar berjumlah $28,89 \%$ kemudian 
pedagang yang taat membayar retribusi pasar pada ketaatan hukum yang bersifat internalizationberjumlah $15,55 \%$.

\section{Pembahasan}

Berdasarkan hasil observasi awal semua pedagang telah taat dalam membayar retribusi pasar setelah melakukan penelitian peneliti menemukan enam orang pedagang yang belum taat dalam membayar retribusi pasar dalam hal ini tidak melakukan pembayaran.

Dalam penelitian ini sebagai mana hasil penelitian dilapangan yang telah dilakukan ketaatan hukum pedagang pasar sabho dalam membayar retribusi pasar terbagi atas tiga jenis:

\section{a. Ketaatan yang bersifat compliance}

Ketaatan yang bersifat compliance adalah persetujuan, merupakan penerimaan secara terbuka terhadap suatu aturan hukum dan mematuhinya karena adanya ketakutan terhadap sanksi atau sebagai suatu usaha menghindari kemungkinan hukuman.

Berdasarkan hasil perolehan angket sebagian besar para pedagang membayar retribusi pasar didasarakan oleh adanya sanksi yaitu 55,55\% sangat disetujui oleh sebagian besar pedagang.

Berdasarkan hasil wawancara dengan ketiga informan diatas bahwa sebagian besar pedagang mematuhi aturan pembayaran retribusi pasar karena adanya sanksi, yaitu dikeluarkan dari pasar jika tidak melakukan pembayaran dengan adanya sanksi yang diterapkan maka sebagian besar pedagang membayar retribusi pasar karena jika tidak maka mereka akan dikeluarkan sehingga dengan adanya sanksi ini ketaatan pedagang meningkat.

\section{b. Ketaatan yang bersifat indentification}

Ketaatan yang bersifat indentification yaitu, penerimaan suatu aturan bukan karena nilai instriknya dan daya tariknya akan tetapi karena keinginan orang untuk mempertahankan keanggotaan di dalam kelompok atau untuk mempertahankan hubungan dengan tokoh-tokoh tertentu, agar hubungan dengan pihak tertentu tidak menjadi rusak.

Berdasarkan hasil angket bahwa 55,55\% pedagang sangat menyetujui membayar retribusi pasar karena adanya sanksi yang diberikan oleh pengelola pasar apabila tidak membayar retribusi pasar, kemudian $31,11 \%$ pedagang membayar retribusi psar karena adanya penghargaan dan $28,89 \%$ pedagang mengatakan membayar retribusi pasar karena takut hubungan dengan petugas pengelola pasar menjadi rusak, sehingga pedagang taat membayar retribusi pasar.

Berdasarkan hasil analisis dengan ketiga informan diatas bahwa sebagian besar pedagang membayar retribusi pasar karena takut sanksi, dan takut hubungan dengan petugas pasar menjadi rusakdan jugaadanya penghargaan kepada petugas pengelola pasar, namun lebih banyak yang takut karena adanya sanksi.

\section{c. Ketaatan yang bersifat Internalization}

Ketaatan yang bersifat internalization yaitu, ketaatan yang berasal dalam diri seseorang, penerimaan seseorang mengenai suatu peraturan atau tingkah laku karena berpendapat bahwa isinya secara instrinsik memberikan imbalan.

Berdasarkan hasil angket bahwa 55,55\% pedagang mengatakan bahwa pedagang membayar retribusi pasar dikarenakan adanya sanksi yang tegas dari 
petugas pengelola pasar, dan $31,11 \%$ pedagang sangat setuju melakukan pembayaran retribusi pasar karena adanya penghargaan dan $28,89 \%$ pedagang membayar retribusi karena takut hubungan dengan petugas pengelola pasar menjadi rusak. kemudian $15,55 \%$ pedagang hanya menyetujui pembayaran retribusi didasarkan atas kesadaran dalam diri pedagang, dari data di atas menyatakan bahwa sebagian besar para pedagang membayar retribusi pasar didasarkan karena adanya sanksi yang tegas yang diberikan oleh petugas pengelola pasar.

Berdasarkan hasil wawancara diatas dengan keempat informan diatas yaitu para pedagang membayar reteribusi pasar karena adanya sanksi, adanya penghargaan,dan adanya manfaat yang diberikan oleh petugas pengelola pasar,kepada pedagang dan adanya kesadaran dari para pedagang. Tetapi lebih banyak yang membayar retribusi pasar karena adanya sanksi yang diberikan oleh petugas pengelola pasar kepada pedagang, sehingga dengan adanya sanksi membuat para pedagang taat dalam membayar retribusi pasar, meskipun terkadang ditemukan 3 sampai 6 orang yang tidak melakukan pembayaran dan terkadang terdapat 5 orang yang hanya membayar setengah dari harga yang ditentukan pengelola pasar, tetapi sudah sebagian besar pedagang taat dalam membayar retribusi pasar.

\section{Upaya Pemerintah Untuk Meningkatkan Ketaatan Hukum Pedagang Dalam Membayar Retribusi Pasar}

Dalam penelitian ini sebagaimana hasil penelitian di lapangan yang telah dilakukan bahwa upaya yang dilakukan untuk meningkatkan ketaatan pembayaran retribusi pasar yaitu upaya pengawasan yang dilakukan petugas pasar Shabo.

\section{Sumber daya manusia}

Menurut Sutrisno (2009:4) sumber daya manusia (SDM) merupakan sekelompok manusia yang bekerja dalam suatu organisasi yang siap, mampu dan siaga dalam menggerakan organisasi dalam mewujudkan eksistensinya. Selain itu SDM juga merupakan suatu aset atau modal utama bagi suatu organisasi dalam mencapai tujuan.

Berdasarkan hasil analisis wawancara bersama empat informan di atas,Bahwa untuk saat ini para petugas penagih retribusi pasarmasih kurang tegas dalam mlakukan penagihan sebab pedagang masih taat dalam melakukan pembayaran, tetapi yang menjadi masalah yaitu petugas penagih yang ditempatkan di kios hanya satu orang petugas penagih, dan berdasarkan hasil wawancara dengan keempat informan tiga yang mengatakan tidak sebanding dengan jumlah pedagang 197 orang yang hanya ditangani satu orang penagih.

\section{Pengelolaan Manajemen}

Menurut Terry dalam Andi (2010:18) definisi manajemen adalah suatu proses yang membeda-bedakan antara perencanaan, pengorganisasian, pelaksanaan, dan pengawasan dengan memanfaatkan baik ilmu maupun seni, agar dapat mencapai suatu tujuan yang telah ditetapkan sebelumnya.

Berdasarkan analisis hasil wawancara dari keempat informan diatas pengelolaan manajemen yang dilakukan oleh Manager pasar Sabho yaitu berupa pelaksanaan pembuatan jadwal penagihan retribusi pasar, untuk masa satu bulan, dan penentuan pemabayaran dalam masa 10 hari bagi pedagang 
sayur, dan pembuatan karcis bagi pedagang ikan untuk yang melakukan pembayaran perhari dengan tujuan agar pembayaran retribusi pasar dapat berjalan lancar.

\section{Pengawasan}

Menurut Revrisond (1999:118) yang dimaksud dengan pengawasan adalah suatu kegiatan untuk memperoleh kepastian apakah pelaksanaan pekerjaan atau kegiatan itu dilakukan sesuai dengan rencana, aturan-aturan sesuai dan tujuan yang telah ditetapkan.

Berdasarkan analisis hasil wawancara dengan keempat informan diatas maka hasil analisis diatas yaitu, para pedagang taat membayar retribusi pasar karena tiap tanggal pembayaran selalu ada utusan masing-masing petugas penagih yang sudah ditugaskan sesuai dengan bidangnya masing-masing untuk menagih masing-masing pedagang yang menggunakan jasa pasar sehingga masing-masing pedagang dapat membayar retribusi pasar tepat waktu. Dan juga adanya proses upaya manajemen yang dilakukan oleh petugas pengelola pasar berupa pembuatan aturan jadwal penetapan pembayaran perbulan, perhari, perminggu dan masa pembayaran yang ditetapkan untuk masa sepluh hari bagi pedagang sayur, serta pembuatan karcis pembayaran bagi pedagang ikan yang melakukan pembayaran perhari dengan adanya aturan, dan proses pengawasan maka pembayaran pasar yang dilakukan sampai saat ini berjalan dengan sangat baik, tetapi yang membuat para pedagang taat membayar retribusi pasar yaitu karena adanya proses pengawasan, dan sanksi.

\section{Regulasi}

Menurut Hartono (2002:69) regulasi merupakan peraturan yang harus dipatuhi oleh orang-orang yang berada dilingkungan internal maupun eksternal organisasi publik dalam rangka mencapai tujuan organisasi.Supaya hukum atau peraturan perundang-undangan dapat benar-benar berfungsi.

Berdasarkan hasil analisis wawancara dengan keempat informan diatas, mengenai pembayaran retribusi pasar yang dilakukan berdasarkan upaya pengelolaan manajemen yang dilakukan oleh manager pasar Sabho mulai dari proses pembuatan aturan pembayaran pasar, proses upaya pengawasan yang disertai dengan sanksi bagi pedagang yang melanggar, dan juga proses regulasi yang diserta sanksi maka dengan ini para petugas pasar, sudah cukup membantu peningkatan pembayaran retribusi pasar, meskipun terkadang ditemukan 3 hingga 6 orang yang tidak melakukan pembayaran dan terkadang 5 orang yang ditemukan membayar setengah harga, dari harga yang ditentukan oleh pengelola pasar tetapi, sudah sebagian besar pedagang telah taat melakukan pembayaran retribusi pasar.

\section{PENUTUP}

\section{Kesimpulan}

Berdasarkan hasil penelitian dan uraian dalam pembahasan, maka dapat disimpulkan sebagai berikut:

1. Ketaatan hukum pedagang dalam membayar retribusi pasar di pasar Sabho Kecamatan Pasarwajo Kabupaten Buton pada tahun 2018 sampai 2019 memiliki tiga ketaatan hukum yaitu: (a) ketaatan yang bersifat complianceartinya pedagang membayar retribusi disebabkan karena takut 
diberikan sanksioleh petugas pengelola pasar (b) ketaatan yang bersifat indentificationyang artinya taat karena takut hubungandengan pihak pengelola pasar menjadi rusak. (c) ketaatan yang bersifatinternalization. Yaitu pedagang taat dalam membayar retribusi pasar karena adanya kesadaran dalam diri pedagang. Namun sebagian besar pedagang taat dalam membayar retribusi pasar karena takut adanya ketaatan hukum yang bersifat complianceyaitu pedagang taat dalam membayar retribusi pasar karena takut adanya sanksi yang diberikan oleh petugas pengelola pasar, apabila tidak membayar retribusi pasar.

2. Upaya-upaya yang selalu digunakan di Pasar Sabho untuk meningkatkan ketaatan hukum pedagang dalam membayar retribusi pasar diantaranya:

a. Pengelolaan Manajemen yaitu dilakukan oleh seorang manager pasar Shaboyang tugasnya memimpin mengarahkan dan menetapkanjadwal pembayaran retribusi pasar baik itu pembayaran yang ditetapkan perhari, maupun perbulan, agar pedagang membayar retribusi sesuai dengan aturan dan waktu yang ditentukan

b. Pengawasan, yaitu para petugas penagih melakukan pengawasan, penagihan,dan pendataanterhadap pedagang yang telah melakukan pembayaran retribusi pasar dan yang belum melakukan pembayaran retribusi pasar, baik itu pembayaran yang ditetapkan perhari, maupun perbulan, agar pembayaran retribusi pasar meningkat.

\section{Saran}

Berdasarkan kesimpulan di atas, maka saran atau rekomendasi yang peneliti ajukan yaitu sebagai berikut:

a. Dari petugaspengelola pasar, harusdapat memberikan pemahaman kepada para pedagang pasar tentang manfaat dan arti penting dari pembayaran retribusi pasar, agar para pedagang membayar retribusi pasar, bukan hanya karena adanya sanksi, ataupun paksaan dari petugas pasar akan tetapi para pedagang membayar retribusi pasar karena bentuk kesadaran dan rasa ikhlas karena telah diberikan pemahaman, akan arti pentingnya pembayaran retribusi pasar.

b. Dari petugas penagih retribusi pasar, jangan hanya melakukan upaya pengawasan dan penagihan retribusi pasar, tetapi harus bisa memberikan pemahaman hukum kepada para pedagang pasar tentang arti pentingnya membayar retribusi pasar dan memberikan penjelasan kepada para pedagang mengenai tujuan dari pembayaran retribusi pasar, serta memberikan sanksi yang tegas bagi siapasaja yang melanggar aturan yang telah ditetapkan, agar para pedagang tidak menyepelekan aturan yang telah ditetapkan baik itu peraturan yang dibuat oleh pemerintah maupun yang dibuat oleh pihak petugas pengelola pasar.

\section{Daftar Pustaka}

Affandi.1998. Pengantar Ilmu Hukum. Bandung: Merpati Group.

Andi Asrul, Samanglangi. 2010. Analysis About Tax Management Areas Insuppoting Revenue in the District Soppeng Jurnal. Universitas Hasanuddin.

Anna Suharso Retno Ningsih, Kamus Besar Bahasa Indonesia, Widya Karya, Semarang 2005

Atosokni Gea, Antonius, dkk. 2002.Relasi dengan Diri Sendiri, Jakarta: Elek Media Komputindo. 
Hamid,Dharma. 2014. Metode Penelitian Pendidikan Sosial. Bandung: Alfabeta.

Hartono Solchan. 2002. Evaluasi fungsi Regulasi dalam pajak daerah dan Retribusi daerah Jurnal. Universitas diPonegoro Semarang.

Hentiani, Tri. 2011. Analisis Faktor-Faktor Yang Mempengaruhi Pendapatan Pedagang Informal Di Pajak Sentral Medan. Jakarta : Elek Media Komputindo.Juli 2019, Pukul 16:20 WIB.

Kamaruddin. 2016. Membangun Kesadaran dan Ketaatan Hukum MasyarakatPerspektifLaw Enfor Cement Jurnal Al-Adi Vol.9 No.2, Juli 2016.

Mardiasmo.2009. Akuntansi Sektor publik. Andi,Yogyakarta.

Payaman, J Simanjuntak. 1998. Pengantar Ekonomi Sumberdaya Manusia. Jakarta: Penerbit FE UI.

Peraturan Daerah Kabupaten Buton Nomor 4 Tahun 2013 Bab 1 tentang retrbusi pelayanan pasar.

Peraturan Daerah Kabupaten Buton No.4 Tahun 2013 Bab V Tentang besarnya tarif retribusi.

Revrisond, Baswir.1999.Akuntansi Pemerintahan Indonesia, Yogyakarta: BPEF Yogyakarta.

Setyawan,Salam.2004.Manajemen Sumber Daya Pemerintah Indonesia. Jakarta: Djambatan.

Sudirmansyah.2011.Pengertian Dan Jenis-Jenis Pasar. Diakses dari http://www. Sudirmansyah.Com/Tag/Pengertian-Pasar Pada Tanggal 30

Sutrisno,Edy. 2009. Manajemen Sumber Daya Manusia. Jakarta: Kencana Prenada Media Group.

Undang-Undang Nomor 28 Tahun 2009 Tentang pajak Daerah dan Retribusi daerah. 